\title{
HLA-A wt Allele
}

National Cancer Institute

\section{Source}

National Cancer Institute. HLA-A wt Allele. NCI Thesaurus. Code C51075.

Human HLA-A wild-type allele is located in the vicinity of $6 \mathrm{p} 21.3$ and is approximately $3 \mathrm{~kb}$ in length. This allele, which encodes HLA class I histocompatibility antigen, A-1 alpha chain protein, is involved in immune system peptide presentation. 